\title{
10 Domestic and Foreign Shocks to Employment and Capital Accumulation in Germany
}

\author{
Oliver Landmann and Jürgen Jerger ${ }^{1}$ \\ UNIVERSITY OF FREIBURG
}

\section{INTRODUCTION}

Current thinking on the causes of Europe's persistent unemployment problem does not accord much weight to open-economy considerations. While there is agreement that the high unemployment of the 1980s reflects an increased level in the non-accelerating inflation rate of unemployment (NAIRU), it is equally clear that the increase recorded since 1980 cannot plausibly be attributed to the same kind of unfavourable supply shocks, including terms-of-trade shocks, which are widely seen as the major cause of rising unemployment in the 1970s (see Blanchard and Summers, 1986). Most recent explanations rely on one variant or another of hysteresis, that is, on the idea that a high equilibrium rate of unemployment may simply reflect a past history of high actual unemployment.

A dissenting view has been put forward by Fitoussi and Phelps (1988) who emphasise the external shock emanating from the dramatic shift in the US policy mix at the beginning of the decade. As a result of this shift, Europe was all of a sudden confronted with a sharply higher level of real interest rates and a skyrocketing US dollar exchange rate. Whereas the dollar appreciation was subsequently fully reversed in the second half of the $1980 \mathrm{~s}$, real interest rates, though moderating somewhat after 1984, remained on a level distinctly higher than the norm of the 1970 s.

In discussing the effects of this external shock, it is useful to distinguish two issues. The first is the question of the short-term transmission mechanism. Here, Fitoussi and Phelps make much of the failure of the traditional Mundell-Fleming model to explain how 
a foreign interest rate shock can be contractionary at home under flexible exchange rates. They follow Sachs (1980), Dornbusch (1983) and others in demonstrating how the traditional result can be reversed once a direct channel of influence between the exchange rate and the price level is taken into account. They also show how pricing behaviour may be affected by a rising real interest rate so as to reinforce the supply-side effects of a depreciating exchange rate. We will not pursue this line of argument in the present chapter.

As far as the remarkable persistence of high unemployment in Europe is concerned, a more important issue is the longer-term effect of the foreign shock on the dynamics of capital accumulation and on the determinants of labour market equilibrium. Here Fitoussi and Phelps emphasise various disinvestment incentives stemming from the sustained rise in the real interest rate. These effects include increased mark-ups in customer-markets; decreased labour hoarding; deferred capital maintenance; depressed prices and production in the capital goods industry and finally - 'more prosaic, yet, as an empirical matter, quite important' to quote Phelps (1989, p. 319) - the cutback of capital formation.

The present chapter reviews the case of Germany in an attempt to assess whether this foreign-interest-rate-shock story is consistent with the major macroeconomic developments since 1980 . We do not wish to set up the Fitoussi-Phelps hypothesis against the mainstream hysteresis hypothesis. In our opinion, it would be pointless to search for discriminating evidence since both hypotheses share a number of implications and are, in any event, best regarded as complementary rather than contradictory. Nor are we about to weigh the relative importance of the various possible channels through which the interest rate shock may have made itself felt. We prefer to follow Fitoussi and Phelps (1988, p. 74) in considering the capital-stock mechanism as 'emblematic of a polymorphous collection of real interest effects'. We thus focus on the role of capital formation and of plain capital-labour substitution.

The core of the chapter consists of a simple model of employment-investment interaction in an open economy. We use the model to link the external-shock story with the voluminous labour market literature focusing on the role of real wage resistance and on measures of the so-called real wage gap. The latter is intended to serve as an indicator of how much real wages are above the level consistent with full employment. Here the empirical labour market literature is confronted with some sort of a paradox: any account 
linking unemployment to a lack of wage flexibility and hence disequilibrium real wages would seem to require that the increase in unemployment recorded since $1979 / 80$ be accompanied and accounted for by an increase in measured real wage gaps. Of course, most of the theoretical stories offered in support of the hysteresis hypothesis, such as the insider-outsider theory, do depend on some measure of real wage rigidity. In fact, however, the experience of the 1980 s offers little evidence of grossly excessive real wages. All the real wage gap indices offered in the literature fell to unprecedented lows while at the same time unemployment soared to levels not seen in recent history.

It is our contention that this seemingly puzzling picture neatly fits into a consistent account of how the German economy responded to the major macroeconomic shocks of the 1970s and 1980s. Our analysis goes back to the early 1970 s when an unprecedented domestic wage explosion ended a long period of full employment and nearprice-stability. This was the episode that revived the interest in the concept of classical unemployment and first led to the construction of real wage gap indices. One decade later, the external real interest shock occurred at a time when the German labour market faced the challenge of absorbing a labour supply bulge caused by demographic factors.

The remainder of the chapter is structured as follows: Section 2 briefly reviews the major macroeconomic developments on which our theoretical interpretation will turn. Section 3 discusses the concept of the real wage gap. In Section 4, our open-economy model of employment and capital formation is developed and used to interpret the stylised facts. Section 5 offers some concluding remarks.

\section{SOME FACTS}

In this section, we take a look at the broad facts with which this chapter is concerned. The data are for the aggregate German economy and the time-span covered is 1961 to 1989 . This period will form a convenient unit of analysis for some time to come as the German unification of 1990 has created a major break in every important time series. While the most conspicuous events in the period under review are certainly the three recessions, a minor one in 1967 and two major ones in 1974/75 and 1981/83, we do not focus on them in particular nor on the monetary turbulences surrounding them, but on the more 
Table 10.1 Selected economic indicators for Germany, 1961-89

\begin{tabular}{lrrr}
\hline Variable & $1961-73$ & $1974-9$ & $1980-89$ \\
\hline Employment (annual percentage change) & 0.2 & -0.1 & 0.3 \\
Labour force (annual percentage change) & 0.2 & 0.1 & 0.8 \\
Unemployment rate (average per cent) & 0.8 & 3.5 & 6.8 \\
Output (annual percentage change) & 4.3 & 2.7 & 2.2 \\
Output per hour (annual percentage change) & 5.1 & 3.8 & 2.5 \\
Real wages (annual percentage change) & 5.1 & 2.4 & 1.9 \\
Capital stock (annual percentage change) & 5.4 & 3.5 & 3.0 \\
Net investment (per cent of NNP) & 21.5 & 13.3 & 10.6 \\
Real interest rate (average per cent) & 2.8 & 3.1 & 4.6 \\
\hline
\end{tabular}

Source: Vierteljährliche Volkswirtschaftliche Gesamtrechnung des Deutschen Instituts für Wirtschaftsforschung (DIW), Berlin; own calculations.

fundamental and more sustained changes in the real, non-monetary indicators of macroeconomic performance which stand out beyond the ups and downs of the business cycle. It is our presumption that these underlying trends of the real economy are shaped by real forces and, accordingly, the monetary history is not taken into account; hence we abstract from short-run real effects of monetary disturbances - which we thereby do not mean to deny.

The developments addressed by our subsequent analysis are summarised in Table 10.1 and Figure 10.1. They concern the trends in output, employment, capital formation, labour costs and the interest rate. We comment briefly on each in turn.

\subsection{Output and Employment}

The $1974 / 75$ recession put an end to more than a decade of almost uninterrupted overemployment during which excess labour demand attracted a large number of immigrant workers and unemployment was negligible. As illustrated in the middle panel of Figure 10.1, the unemployment rate then rose sharply in each of the two major recessions and in each case failed to return to its previous level. Employment remained virtually stagnant. While it is true that an acceleration of labour force growth in the 1980 s placed an additional strain on the flexibility of the labour market, the continued slowdown of output growth and productivity growth strongly suggested the continued operation of some factor which depressed labour demand. 

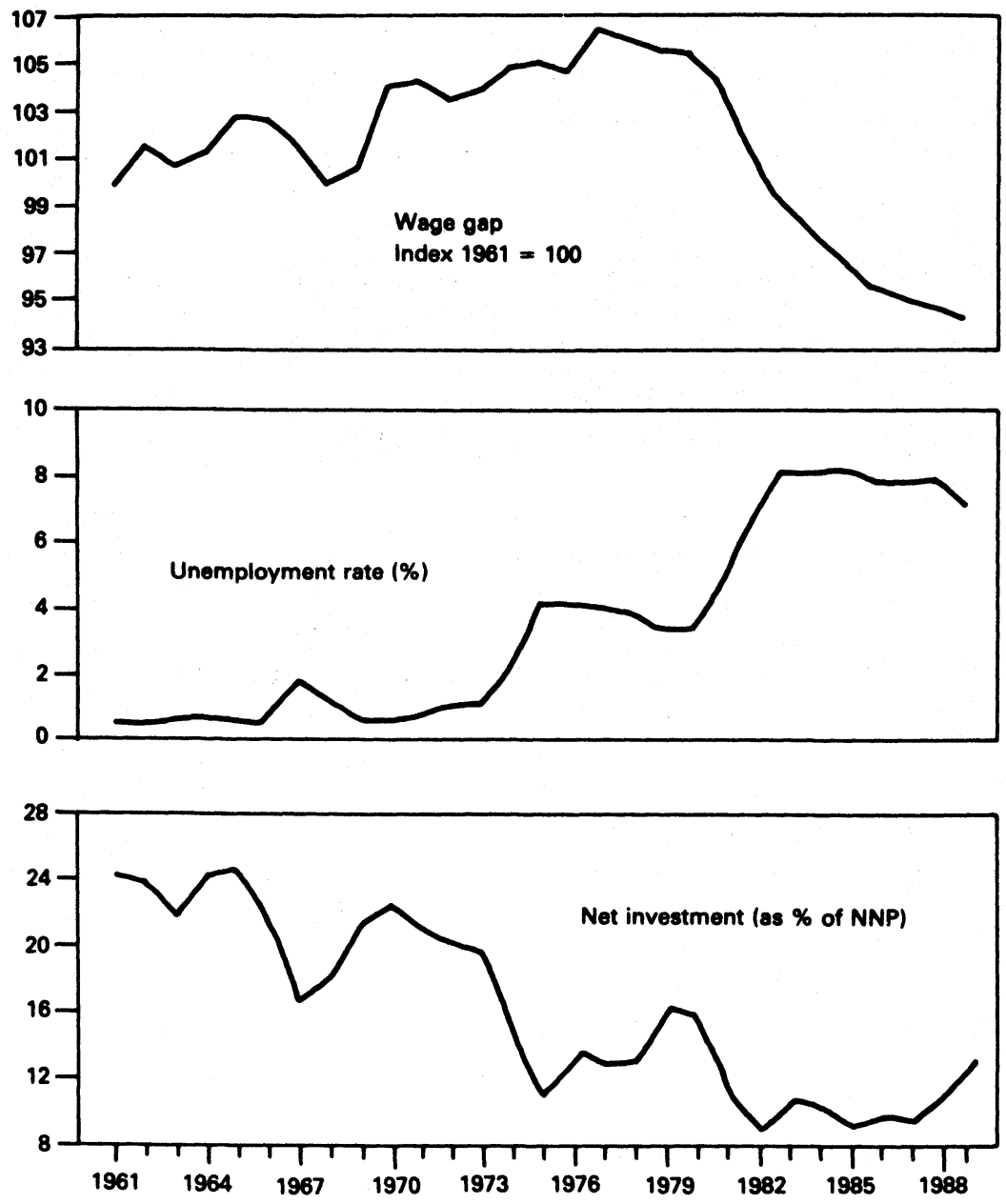

Figure 10.1 Wage gap, unemployment rate and net investment in Germany, 1961-89

Source: See Table 10.1.

A convincing account of the employment record should be able to identify this factor.

\subsection{Real Wages}

Excessive real wage growth, widely considered the principal cause of rising unemployment, appeared harder and harder to blame, as 
unemployment remained high and rose even higher in the 1980s. While the declining trend of real wage growth in the sub-periods shown in Table 10.1 conceals significant variations within the subperiods, the time-path of the real wage gap index displayed in the top panel of Figure 10.1 casts serious doubt on the hypothesis that real wages are stuck on too high a level. ${ }^{2}$ The wage gap, calculated as an index of the real wage level relative to trend productivity (as explained in more detail in Section 3), indeed rose sharply in the early 1970 s, immediately before the first significant increase in the unemployment rate. This reflected the well-documented 1969-74 wage explosion (see, for example, Sachs, 1979) coinciding with, and exacerbated by, the productivity slowdown and other supply shocks. However, the wage gap declined steadily in the late 1970s and throughout the 1980s when unemployment rose still higher. Any model of unemployment is challenged to explain this changing pattern in the relative movement of real wages and employment.

\subsection{Capital Formation}

The net investment ratio, plotted in the bottom panel of Figure 10.1, displays the usual cyclical variations around an apparently declining long-term trend. The fall in investment was particularly steep in the first half of the 1970s. Another sharp cutback occurred in the early 1980s when the investment ratio sank to an unprecedented low from which it did not begin to recover until late in the decade. The slowdown of investment spending naturally translated into a falling growth rate of the capital stock. While the capital stock continued to grow more rapidly than employment, as one would expect in the normal course of economic growth, a rough comparison of the two growth rates in the three sub-periods of Table 10.1 reveals a significant slowdown in capital stock growth. Although the data alone do not reveal how much of this slowdown is attributable to a slowdown of (labour-augmenting) technical progress, it appears highly unlikely that any story about labour being displaced by capital can account for the poor employment record. As we pointed out in the introduction, the disinvestment process will occupy centre stage in our analysis.

\subsection{Real Interest Rate}

The last row of Table 10.1 presents period averages of the longterm real interest rate. Although it was subject to numerous real and monetary disturbances throughout the period under review, the 
real interest rate never departed systematically from the historical norm of about 3 per cent up to the late 1970s. At that time, the level of world real interest rates increased sharply. The German economy, linked to the world financial system by unrestricted capital flows, could not escape this general trend. It is noteworthy, however, that Germany experienced less of a real interest rate shock than many other European countries at that time. These differences are presumably due to the fact that, on the whole, the rest of Europe experienced a much more pronounced transition from inflation to disinflation at this juncture. Still, the increase in the level of German real interest rates was far from negligible.

\section{THE CONCEPT OF THE REAL WAGE GAP ${ }^{3}$}

Ever since it became customary to discuss persistent unemployment in terms of the real wage gap, the concept was meant to measure the discrepancy between the actual real wage and what it ought to be in order not to stand in the way of full employment. Also, it was always realised that any comparison of actual real wage levels with the levels prevailing in earlier times of full employment must allow for so-called 'warranted' real wage increases that would have taken place even under permanent full employment. The difficult part is how to determine what is 'warranted'.

The simplest and least sophisticated, but also the most popular, way of answering this question is to adjust actual real wage growth for actual productivity growth - as in Calmfors and Nymoen (1990, Table 1), to cite but one recent example. More sophisticated approaches try to take into account the fact that excess real wage growth endogenously generates additional productivity growth as firms are forced to move up their labour demand curves. Depending on how easily labour and other factors of production can be substituted for each other, any excess real wage growth will appear at least in part 'to pay for itself'.

Suppose output $Y$ is a function of capital $K$, labour $N$ and time $t$ :

$$
Y=F(K, N, t)
$$

If this production function exhibits constant returns to scale (CRS) and a constant elasticity of substitution, and if we assume competitive profit-maximising firms, the first-order condition governing the 
labour demand behaviour of firms yields the following log-linear relationship between the average product of labour and the real wage (with lower-case letters, except $t$, denoting logs):

$$
y-n=\alpha_{0}+\sigma(w-\lambda t)+\lambda t
$$

In this equation, $w$ is the $\log$ of the real wage, $\alpha_{0}$ is a constant, $\sigma$ is the elasticity of substitution and $\lambda$ is the rate of autonomous productivity change due to technical progress. In the limiting case of the CobbDouglas production function $(\sigma=1)$, productivity moves one-to-one with the real wage so that any real wage growth appears 'justified' $e x$ post by the resulting productivity growth. ${ }^{4}$ More generally, (2) can be interpreted as saying that labour productivity deviates from its longterm trend whenever the real wage deviates from this same trend. The trend deviation of the real wage, $w-\lambda t$, is what Gordon (1988, p. 287) has called the 'adjusted wage gap'. By relating the real wage to trend productivity rather than actual productivity, this measure is presumed free of any bias stemming from endogenous productivity changes. We can rewrite (2) so as to make plain how the adjusted wage gap is related to the unadjusted wage gap, where the latter is simply an index of the wage share in national income:

$$
w+n-y=-\alpha_{0}+(1-\sigma)(w-\lambda t)
$$

Obviously, the wage share moves in the same direction as the adjusted wage gap if the elasticity of substitution falls short of unity. The wage gap index plotted in Figure 10.1, above, is based on estimates of Equations (2) and (3) reported in Landmann and Jerger (1991). In line with most other studies, these estimates imply a value of $\sigma$ significantly and substantially below unity.

\section{CAPITAL ACCUMULATION AND EMPLOYMENT IN AN OPEN ECONOMY}

We now turn to the question of how the changing pattern in the relative movement of the adjusted real wage gap and employment can be explained. As pointed out in the introduction, the sustained decline of real wages relative to labour productivity since the mid1970 s is widely taken as first-hand evidence that unions have learnt the bitter lessons of the early 1970s and have moderated their wage 
claims in the face of continued high unemployment. Far-reaching conclusions have been derived from this interpretation for both analysis and policy. In particular, many economists have questioned the empirical relevance of theories that explain persistent unemployment as a manifestation of persistent aggregate excess supply on the labour market stemming from inadequate real wage flexibility, no matter what particular rigidity is thought to be at work. Union leaders, in turn, feel that they have distributive justice on their side, and economic reason not against them, as they attempt to recover lost ground after years of adverse redistribution.

To see what is wrong with this type of conclusion, we consider a simple model of capital stock determination, wage-setting behaviour and employment in an open economy. The model abstracts from monetary and other demand side disturbances which may entail short-run real effects. The focus is entirely on the longer term response of unemployment and the wage gap to changes in wage setting, capital formation and the labour force. To simplify matters, the theoretical analysis assumes away autonomous productivity change due to technical progress so that the real wage can directly be identified with the adjusted real wage-gap index as derived above. In the same way, the model generates stationary equilibrium values of the capital stock and the capital-labour ratio that are therefore best interpreted as trend-adjusted.

Starting from the CRS production function (1), and suppressing the time trend, we can write the marginal product of labour $F_{N}$ as a function of the capital-labour ratio which is equated to the real wage $W$ by profit-maximising employers:

$$
W=F_{N}(K / N)
$$

Wage setters are assumed to aim at a real wage target which depends on the state of the labour market represented by the rate of employment:

$$
W=z(N / \bar{N})^{\beta}
$$

$\bar{N}$ is the labour force, $\beta$ is a measure of what is commonly referred to as 'real wage flexibility'. The shift parameter $z$ captures all other real forces that impinge on the wage bargain (the wedge between the consumption wage and the producer wage, the militancy and bargaining strength of unions, unemployment benefits and so on). ${ }^{5}$ Equa- 
tions (4) and (5) together determine a labour market equilibrium in the sense that the real wage outcome intended by wage-setters according to (5) is consistent with the demand price of labour derived from (4). Since the wage bargain is cast in nominal terms, actual outcomes may differ from the equilibrium solution due to expectational errors and nominal rigidities as analysed by Blanchard (1990). Any such disequilibrium sets in motion a wage-price spiral which must eventually end, however, when monetary accommodation stops and the authorities adjust nominal demand growth so as to force output and employment back to their equilibrium levels (Layard and Bean, 1989). Equilibrium employment can thus be thought of as the level associated with the NAIRU. As noted abovê, we are not concerned with deviations from the NAIRU in this ehapter. The position of the labour market equilibrium obviously depends on the capital stock which in turn gradually adjusts to its optimal level determined by the condition that the net marginal product of capital $F_{K}$ be equal to the cost of capital $r^{*}$.

$$
F_{K}(K / N)=r^{*}
$$

Due to the openness of the economy, the cost of capital is assumed to be given exogenously from the world capital market. Equations (6), (4) and (5) - in this order - recursively determine the capital-labour ratio, the real wage (or adjusted real wage gap) and the rate of (un)employment. The implied interaction of capital formation and employment is visualised in Figures 10.2 and 10.3 which depict the consequences of changes in the wage-setting process, world capital market conditions and the labour force, respectively. In both figures, the top panel depicts the capital-labour ratio as determined by the exogenous cost of capital according to Equation (6). In the bottom panel, the $N^{d}$ schedule represents labour demand as given by Equation (4) and the WS schedule represents the wage-setting Equation (5).

Suppose there is an exogenous shock to the wage-setting process such as the widely analysed European wage explosion of the early 1970s, as discussed for example by Sachs (1979). This is depicted in Figure 10.2. Assuming an initial equilibrium at point $A$ (in both panels), the wage-setting schedule $W S$ is shifted upwards leading to a new transitory equilibrium with a higher real wage and lower employment at point $B$. While the capital stock cannot respond immediately, firms find themselves with a higher than desired capital-labour ratio 


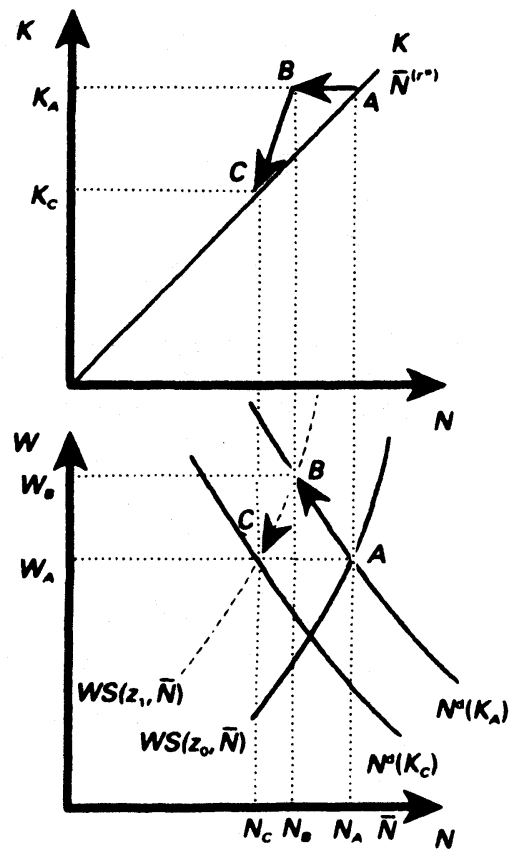

Figure 10.2 A wage shock

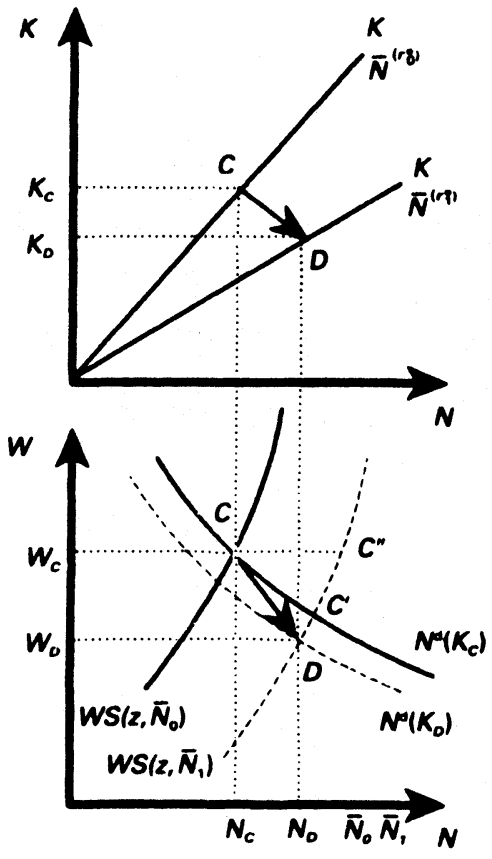

Figure 10.3 An interest rate shock and a labour force increase

and thus begin to reduce their capital stock by cutting back on investment spending. This in turn lowers the marginal productivity of labour so that the $N^{d}$ schedule shifts down. As a consequence, employment falls even further, thus strengthening the disinvestment incentives of firms. The adjustment process comes to an end at point $C$ (in both panels of the figure), whəre the initial capital-labour ratio and hence the initial real wage level are re-established at a lower rate of employment $\left(N_{C}\right)$.

Two major points emerge from this analysis. Firstly, the push for higher wages not only depresses employment directly, by forcing firms up their labour-demand schedules, but also indirectly, by setting off a disinvestment process. Secondly, an increase in the real wage gap occurs only temporarily, as long as the capital stock has not yet fully adjusted to its new steady-state level $\left(K_{c}\right)$. In contrast, the higher unemployment caused by the wage-setting shock is permanent. It thus becomes clear that the concept of the real wage gap does not tell us anything useful about whether wage behaviour gives 
adequate consideration to the requirements of full employment. In fact, with the real wage endogenously determined by the equilibrium capital-labour ratio, it is meaningless to ask what real wage level is consistent with full employment. Thus the very concept of a real wage gap is ill-defined. ${ }^{7}$

The simple exercise presented in Figure 10.2 roughly replicates the experience of Germany and a number of other European economies during the 1970s. After a parallel rise in unemployment and the real wage gap in the first half of the decade unemployment remained high, while the real wage gap (and the labour share) began to decline and the investment ratio remained low. In the same vein, we can ask how our model economy responds to a rise in the world real interest rate and to an increased flow of entrants into the labour force, which were characteristics of the 1980 s as shown in Table 10.1, above. The analysis of this case is given in Figure 10.3. The two exogenous forces shift two schedules. In the upper panel, the ray representing the equilibrium capital-labour ratio rotates downwards in response to the higher cost of capital. In the lower panel, the labour force is assumed to increase from $\bar{N}_{0}$ to $\bar{N}_{1}$. As we can infer from Equation (5), the WS schedule shifts to the right by an amount exactly equal to the proportional increase in the labour force. Starting from an initial equilibrium at point $C$, firms curtail their domestic investment spending so as to adjust their capital stock downwards to the lower level warranted by the higher world real interest rate $r_{1}^{*}$. As a consequence, the labour demand schedule in the lower panel shifts downwards impeding the absorption of the increase in the labour force. Additional workers could have been employed along the path $C C^{\prime}$ with a temporarily given capital stock and, with an unchanged real interest rate $r_{0}^{*}$, investment would have taken place to restore the capitallabour ratio and the unemployment rate to their initial level (at point $\left.C^{\prime \prime}\right)$. With the simultaneous interest rate shock, however, the induced disinvestment process limits the scope for increases in employment and instead places additional downward pressure on the real wage. ${ }^{8}$ The adjustment process thus takes place along the path $C D$ (in both panels). ${ }^{9}$

The adjustment pattern of capital formation is perhaps where the openness of the economy matters most. In a closed economy, a sustained shortfall of investment, however caused, would sooner or later force down the real interest rate as savings have nowhere else to go. In the (small) open economy, in contrast, international capital mobility essentially disconnects the saving process from the dynamics 
of investment. Disturbances to either have no lasting effects on the interest rate, but are absorbed by capital flows and accordingly show up in the current account. ${ }^{10}$ Despite the doubts about this view raised by Feldstein and Horioka (1980), this is pretty much what happened in the case of Germany whose current account surplus ballooned in the 1980s under the pressure of excess savings.

The other predictions of the model were also borne out by the experience of the 1980s. Anaemic employment growth, far too low to absorb the substantial increase in the labour force, a marked decline in the real wage gap and the labour share, and a sustained weakness of investment spending are the most salient features of the German macroeconomic performance since 1980 as summarised in Figure 10.1 and Table 10.1, above. Discussing the consequences of weak domestic capital formation in Germany, the OECD (1988, p. 53) aptly diagnosed a 'vicious circle' of sluggish capacity growth and job creation in which 'weak economic growth eventually began feeding upon itself'. The mutually depressing effects of falling output and employment on investment and of the falling capital stock on labour demand, are indeed the central mechanism driving the contractionary adjustment process portrayed in Figures 10.2 and 10.3.

\section{SUMMARY AND CONCLUSIONS}

After a disappointing macroeconomic performance in the 1970s, much of Europe did even worse in the 1980s - except, perhaps, for the inflation record. Unemployment soared, output and productivity growth continued to slow down, real wages increased even less than productivity, and capital formation was down. According to the hypothesis advanced by Fitoussi and Phelps (1988), this dismal record is not just a consequence of widely-blamed 'Eurosclerosis' but a direct outgrowth of the dramatic increase in the world real interest rate which, in turn, is mainly attributed to the enormous American thirst for capital. In this chapter, we have reviewed the major macroeconomic developments in Germany up to 1989 and attempted to account for these developments within a simple analytical framework. Using a simple model of capital formation and employment in an open economy, we distinguished three major exogenous events that affected the German labour market from 1970. The first was the wage explosion which occurred in the early 1970 s, ending the 'golden age' of rapid economic growth and continuous full employment. The 
second was the foreign interest rate shock of the early 1980s emphasised by Fitoussi and Phelps. The third was the relatively rapid expansion of the labour force in the 1980s. The broad pattern of investment, employment and real wage growth predicted by the model conforms reasonably well to actual experience.

We have devoted particular attention to the concept of the real wage gap which is widely used to appraise the consistency of wage behaviour with the requirement of full employment. The sustained decline of the wage gap since the second half of the 1970s, often regarded as puzzling in view of the dramatic rise of unemployment, is not hard to explain within our analytical framework. The model does not contradict the idea that excessive wage pressure is to blame for high unemployment, but it contradicts the idea that the wage gap, as usually calculated, is a useful indicator of such wage pressure. Although an autonomous wage push does cause an increase in the measured wage gap, we have shown that this increase is reversed over time even though unemployment continues to rise as firms are induced to adjust their capital stock downwards. Similarly, an exogenously caused slowdown of capital formation and an increase in the labour force can both be shown to depress the measured real wage gap indices although both contribute to higher unemployment in the presence of real wage resistance.

According to our model, changes in the labour force have only transitory effects on the real wage gap and the unemployment rate. Changes in wage-setting behaviour relative to trend productivity growth have transitory effects on the real wage gap, but permanent effects on the unemployment rate. Changes in the desired capital intensity of production, in contrast, permanently affect the real wage gap and the unemployment rate. Certainly, one may feel somewhat uncomfortable with the notion that the wage bargain does not eventually respond endogenously to changes in the pace of technical progress and capital accumulation other than via changes in unemployment. If wage-setters smoothly adapted to all changes in productivity growth, unemployment ought to be immune to such changes (Bean, 1989). However, a large body of evidence suggests that this learning process is at best very slow. ${ }^{11}$ In the 1980 s, the fall of the real wage gap and the labour share was widely regarded as proof that the learning process had taken place after all. We have argued above, however, that the adjustment of the desired capital-labour ratio in response to the higher world real interest rate made a fall in the real wage gap inevitable, whatever the flexibility of wage-setting behaviour. 
In view of the difficulties that high real interest rates have caused in the 1980s, various observers, for example Phelps (1989), have condemned the massive American borrowing on the global capital markets as a beggar-thy-neighbour manoeuvre. From the German perspective, however, this reproach hardly appears tenable. Endowed with a high propensity to save, Germany has been a net capital exporter for most of the post-war era. What should a country be thought to experience when one of its export items suddenly fetches a much higher price on the world market? A welfare loss? If 'one can reasonably condemn recent American policy' for draining the world capital market, as Phelps (1989) suggests, this may be a valid point with respect to the indebted less developed countries (LDCs) and other regions that are short of domestic savings. But in the case of Germany, the failure to turn a potentially welfare-improving opportunity on the world capital market into a real-income gain rather than into rising unemployment is entirely self-inflicted.

The lesson to be learned is that, in an open economy, workers and their representatives must recognise the constraints created by the asymmetry between internationally mobile capital and (relatively) immobile labour. With the price of capital determined on the world market, the factor-price frontier does not leave any degree of freedom for the domestic price of labour. For labour as a whole, the pursuit of distributional ambitions in recurrent wage rounds, at best yields transitory income gains, whereas the resulting unemployment is permanent. For the unions, there is good news and bad news in this lesson. The bad news is that a sustainable improvement in the unemployment situation requires a moderation of wage aspirations, even after years of low real wage growth and a falling wage share. The good news is that such moderation, while amounting to a real income loss for employed workers in the short run, spurs domestic capital formation, which in time redresses the initial real wage position as the economy moves to lower unemployment.

The rapid completion of German economic and monetary union in 1990 has confronted the employment system with a challenge of an entirely different dimension. We have not addressed the new situation in this chapter. But the integration of a region which is hopelessly undercapitalised and at the same time inhabited by a workforce eager to catch up with western living standards and willing to move in large numbers to where the good jobs are, is bound to drive home forcefully the importance of the mutually reinforcing interaction of capital formation and employment emphasised by our analysis. 
Decision-makers in all domains of public policy share the responsibility for turning this interdependence into a virtuous rather than a vicious circle.

\section{Notes}

1. The authors are grateful to Søren Bo Nielsen, discussant and the participants of the Conference for their helpful comments.

2. This was noted by various writers; see e.g. Gordon (1988).

3. For a more thorough treatment of the conceptual and empirical foundations of the real wage gap, see Krugman (1987) and Schultze (1987).

4. This observation has led some economists to question the usefulness of productivity-related wage guidelines; see Hellwig and Neumann (1987).

5. In the context of a growing economy, $z$ would also have to capture the influence of anticipated productivity growth.

6. We do not explicitly model the adjustment process in this chapter. For an account of the joint investment and employment dynamics within a rigorous optimising framework, see Burda (1988) and Landmann and Jerger (1991).

7. Robert Solow $(1986$, p. 527$)$ has made the same point in a somewhat related context: '(the real wage) is not for wishing: wishing should be reserved for exogenous variables ...'

8. Depending on the relative size of the changes in the interest rate and the labour force, the net employment change could also turn out negative.

9. This analysis assumes that the labour force increases gradually. With a sudden increase, the adjustment would take place along the path $C C^{\prime} D$.

10. See Sachs (1981) and Blanchard and Fischer (1989, section 2.4) for formal treatments of these current account mechanics.

11. For instance, in Phillips-curve estimates for Germany, Franz (1984 and 1987) has found a significantly less than proportional response of nominal wages to changes in productivity growth.

\section{References}

Bean, C. (1989) 'Capital Shortages and Persistent Unemployment', Economic Policy, vol. 8.

Blanchard, O. (1990) 'Unemployment: Getting the Question Right - and Some of the Answers', in J. Drèze and C. Bean (eds.) Europe's Unemployment Problem (Cambridge: Cambridge University Press).

Blanchard, O. and Summers, L. (1986) 'Hysteresis and the European Unemployment Problem', NBER Macroeconomics Annual 1986. 
Blanchard, O. and Fischer, S. (1989) Lectures on Macroeconomics (Cambridge: Cambridge University Press).

Burda, M. (1988) 'Is There a Capital Shortage in Europe?', Weltwirtschaftliches Archiv, vol. 124.

Calmfors, L. and Nymoen, R. (1990) 'Real Wage Adjustment and Employment Policies in the Nordic Countries', Economic Policy, no. 11.

Dornbusch, R. (1983) 'Flexible Exchange Rates and Interdependence', IMF Staff Papers, vol. 30.

Feldstein, M. and Horioka, C. (1980) 'Domestic Saving and International Capital Flows', Economic Journal, vol. 90.

Fitoussi, J.-P. and Phelps, E.S. (1988) The Slump in Europe (Oxford: Basil Blackwell).

Franz, W. (1984) 'Wohin treibt die Phillipskurve?', Zeitschrift für Wirtschafts- und Sozialwissenschaften, vol. 104.

Franz, W. (1987) 'Hysteresis, Persistence, and the NAIRU: An Empirical Analysis for the Federal Republic of Germany', in Layard, R. and Calmfors, L. (eds), The Fight Against Unemployment (Cambridge: Cambridge University Press).

Gordon, R. (1988) 'Back to the Future: European Unemployment Today Viewed from America in 1939', Brookings Papers on Economic Activity, no. 1.

Hellwig, M. and Neumann, M. (1987) 'Economic Policy in Germany: Was There a Turnaround?', Economic Policy, no. 5.

Krugman, P. (1987) 'Slow Growth in Europe: Conceptual Issues', in Lawrence, R. and Schultze, C. (eds), Barriers to European Growth (Washington).

Landmann, O. and Jerger, J. (1991) 'Domestic Wage Shocks, Foreign Interest Rate Shocks and the Wage Gap in an Open Economy: The Case of Germany', Diskussionspapier des Instituts für allgemeine Wirtschaftsforschung der Universität Freiburg, April 1991.

Layard, R. and Bean, C. (1989) 'Why Does Unemployment Persist?', Scandinavian Journal of Economics, vol. 91.

McCallum, J. (1985) 'Wage Gaps, Factor Shares and Real Wages', Scandinavian Journal of Economics, vol. 87.

OECD (1988) Economic Surveys - Germany, 1987/88, Paris.

Phelps, E. (1989) 'New Channels in the Transmission of Foreign Shocks', in Calvo, G. et al. (eds), Debt, Stabilization and Development (Oxford: Oxford University Press).

Sachs, J. (1979) 'Wages, Profits, and Macroeconomic Adjustment: A comparative Study', Brookings Papers on Economic Activity, no. 2.

Sachs, J. (1980) 'Wages, Flexible Exchange Rates, and Macroeconomic Policy', Quarterly Journal of Economics, vol. 94.

Sachs, J. (1981) 'The Current Account and Macroeconomic Adjustment in the 1970s', Brookings Papers on Economic Activity, no. 1 .

Schultze, C. (1987) 'Real Wages, Real Wage Aspirations, and Unemployment in Europe', in Lawrence, R. and Schultze, C. (eds), Barriers to European Growth (Washington).

Solow, R. (1986) 'Unemployment: Getting the Questions Right', Economica, vol. 53 (supplement). 
